\title{
FAKTOR-FAKTOR PENGHAMBAT PENDATAAN PENERIMA BANTUAN IURAN (PBI) BPJS KESEHATAN DIKELURAHAN HELEDULULAA UTARA KECAMATAN KOTA TIMUR KOTA GORONTALO
}

\author{
Deasinta Rian Hepat \& Ellys Rachman \\ STIA Bina Taruna Gorontalo \\ bukujurnalstia@binataruna.ac.id ${ }^{1}$ \& ellysrachman12@gmail.com2
}

\begin{abstract}
ABSTRAK
Penelitian ini bertujuan untuk mengetahui Faktor-Faktor Penghambat Pendataan Penerima Bantuan Iuran (PBI) BPJS Kesehatan Di Kelurahan Heledululaa Utara Kecamatan Kota Timur Kota Gorontalo. Metode penelitian ini menggunakan jenis deskriptif pendekatan kualitatif. Tehnik pengumpulan data dilakukan melalui wawancara mendalam kepada sejumla informan, observasi dan pencatatan data sekunder yang berkaitan dengan permasalahan penelitian.

Hasil penelitian menyimpulkan bahwa dilihat dari aspek pengetahuan petugas pendata masih cukup rendah. Hal ini terlihat dari masih adanya pendata yang kebingungan dalam melakukan pendataan penerima bantuan iuran (PBI) BPJS dikarenakan kurangnya pelatihan ataupun bimbingan teknis mengenai panduan teknis pendataan tersebut. Selain itu tingkat pendidikan para petugas juga masih rendah sehingga tidak memiliki kemampuan untuk mengoperasikan komputer. Dilihat dari aspek sistem pendataan yang dilakukan oleh para petugas pendata masih sangat sederhana. Hal ini terlihat dari fasilitas atau alat yang digunakan oleh para petugas berupa buku album, dan pulpen atau spidol dan panduan teknis pendataan.Dilihat dari aspek verifikasi dan validasi yang dilakukan masih belum maksimal. Hal ini terlihat dari ketidakhadiran sebagian masyarakat pada saat pelaksanaan rapat atau pertemuan yang membahas verifikasi dan validasi data sehingga data yang ada tidak dapat diperbaharui dan terkesan lama.

Disarankan perlunya meningkatkan pengetahuan dan wawasan petugas pendata dengan memberikan bimbingan teknis atau mengikutsertakan petugas pendata dalam pelatihan-pelatihan tentang panduan tehnik pendataan Penerima Bantuan Iuran (PBI) BPJS Kesehatan.Perlunya mengubah sistem pendataan atau yang digunakanoleh petugas pendata dengan memfasilitasi petugas pendata dengan fasilitas atau alat yang lebih canggih seperti komputer ataupun smartphone.Perlunya menyadarkan masyarakat akan pentingnya rapat pertemuan verifikasi dan validasi data penerima bantuan iuran (PBI), serta lebih giat menginformasikan jadwal rapat atau pertemuan kepada masyarakat.
\end{abstract}

Kata Kunci: Pendataan; Penerima; Bantuan; Iuran

PEDAHULUAN

Kesehatan merupakan suatu faktor penting bagi manusia, ketika kesehatan seseorang dalam kondisi yang tidak optimal, sangat mungkin bahwa segala sesuatu yang harus 
dikerjakan menjadi terganggu hal ini karena kesehatan merupakan kebutuhan mendasar bagi setiap manusia untuk dapat melakukan aktifitas-nya sehari-hari, "Di dalam tubuh yang sehat maka tersimpan jiwa yang kuat", kata-kata mutiara tersebut tentunya sering kita dengar. Dengan memiliki tubuh yang sehat maka kita juga dapat melakukan aktifitas keproduktifitasan sehari-hari seperti: Berdagang bagi pedagang, bekerja bagi pekerja, bertani bagi petani, dll. Dalam Indeks Pembangunan Manusia (IPM), kesehatan adalah salah satu komponen utama selain pendidikan dan pendapatan Dalam Undangundang Nomor 23 tahun 1992. Oleh karena itu Kesehatan merupakan investasi untuk mendukung pembangunan ekonomi serta memiliki peran penting dalam upaya penanggulangan kemiskinan. Pembangunan kesehatan harus dipandang sebagai suatu investasi untuk meningkatkan kualitas sumber daya manusia.

Pemerintah bertanggung jawab untuk menjamin terpenuhnya hak hidup sehat bagi seluruh penduduk Indonesia yang mampu maupun penduduk miskin atau tidak mampu, bertanggung jawab atas ketersediaan sumber daya di bidang kesehatan yang adil dan merata bagi seluruh masyarakat yang memperoleh derajat kesehatan yang setinggitingginya.

$$
\text { Untuk mewujudkan }
$$

terjaminnya hidup sehat, kewajiban pemerintah dalam menjamin rakyatnya dalam hal kesehatan juga diamanatkan oleh Undang-Undang No. 40 Tahun 2004 bahwa pemerintah seharusnya menjamin kesehatan seluruh masyarakat termasuk masyarakat tidak mampu dan miskin. Oleh sebab itu maka perlu menyediakan program pembangunan di bidang kesehatan. Hal ini yang menjadi salah satu faktor penyebab perlunya peningkatan kualitas kesehatan yang ada di Indonesia.

Salah satu program pemerintah guna mendukung pencapaian pembangunan dalam bidang kesehatan adalah diberlakukannya BPJS (Badan Penyelenggara Jaminan Sosial). Ini adalah salah satu program andalan pemerintah dalam hal penjaminan kesehatan masyarakat di Indonesia. BPJS berfungsi menyelenggarakan program jaminan kesehatan. Jaminan Kesehatan menurut UU SJSN diselenggarakan secara nasional berdasarkan prinsip asuransi sosial dan prinsip ekuitas, dengan tujuan menjamin agar peserta memperoleh manfaat pemeliharaan kesehatan dan perlindungan dalam memenuhi kebutuhan dasar kesehatan.

Adapun Kepesertaan BPJS Kesehatan terbagi menjadi 2 kelompok besar yaitu Peserta Bukan Penerima Bantuan Iuran (Non PBI) dan peserta Penerima Bantuan Iuran (PBI). Dimana peserta non PBI meliputi Pekerja Penerima Upah dan pekerja bukan penerima Upah. Sedangkan Peserta Penerima Bantuan Kesehatan (PBI) adalah masyarakat miskin dan tidak mampu dimana iurannya dibayar oleh pemerintah. Seperti yang tertuang dalam Peraturan Pemerintah No. 101 Tahun 2012 tentang Penerima Bantuan Iuran kesehatan yang selanjutnya disebut (PBI) adalah fakir miskin dan orang tidak mampu sebagai peserta jaminan program kesehatan, dimana fakir miskin adalah orang yang sama sekali tidak mempunyai sumber mata 
pencaharian dan/atau mempunyai sumber mata pencaharian tetapi tidak mempunyai kemampuan memenuhi kebutuhan yang dasar yang layak bagi kehidupan dirinya dan/atau keluarganya, sedangkan orang tidak mampu adalah orang yang mempunyai sumber mata pencaharian, gaji atau upah, yang hanya mampu memenuhi kebutuhan dasar yang layak namun tidak mampu membayar iuran bagi dirinya dan keluarganya.

Adapun mekanisme pengajuan warga masyarakat sebagai peserta BPJS (PBI) yaitu pertama-tama data yang diambil dari kelurahan atau desa kemudian diserahkan kepada dinas sosial Kabupaten/Kota kemudian dari Dinas sosial kabupaten/kota dilanjutkan dengan menerbitkan rekomendasi penghapusan atau penambahan peserta PBI JKN ke Dinas Sosial Provinsi dari Dinas Sosial Provinsi kemudian diteruskan ke Kementerian Sosial untuk meneribitkan SK penghapusan/penambhan peserta PBI. Kementerian Sosial meneruskan ke Kementerian Kesehatan untuk didaftarkan ke BPJS Kesehatan untuk kemudian dicetak dan distribusikan ke kelurahan atau desa.

Pendataan merupakan hal yang sangat penting dalam menentukan siapa saja warga yang berhak menjadi penerima bantuan iuran (PBI) BPJS Kesehatan ini, pendataan yang baik dilakukan dengan memperhatikan panduan teknis dan pentingnya pengetahuan petugas pendata mengenai mekanisme panduan pendataan diperlukan agar data yang diambil akurat sehingga penerima bantuan iuran benar-benar masyarakat miskin dan kurang mampu. Selain itu proses validasi dan verifikasi yang dilakukan secara berkala juga menjadi kunci utama agar penerima bantuan iuran tetap dapat terpantau dan perbaharui. Pendataan yang terlaksana dengan baik tentunya dapat membuat progam ini terlaksana dengan efektif dan efisien.

Kantor Kelurahan Heledulaa Utara menjadi salah satu instansi yang berperan penting dalam melakukan pendataan masyarakatnya baik dari segi ekonomi maupun kesehatan. Terutama untuk masyarakat miskin yang dinggap layak menjadi penerima bantuan iuran (PBI) JKN BPJS Kesehatan, Penerima Bantuan Iuran (PBI) telah terhitung 6 tahun sejak ditetapkan melalui Peraturan Pemerintah No. 101 Tahun 2012 dengan jumlah masyarakat yang menerima bantuan program BPJS PBI hingga tahun 2017 adalah sebanyak 397 orang dari 1226 KK. Namun kenyataannya bahwa di Kelurahan Heledulaa Utara Kecamatan Kota Timur pendataan Penerima Bantuan Iuran BPJS Kesehatan belum dilaksanakan dengan baik. Karena ada beberapa permasalahan pendataan penerima bantuan iuran BPJS Kesehatan.

Hal ini dilihat dari masih adanya warga miskin yang belum terdata sebagai Penerima Bantuan Iuran BPJS Kesehatan. selain itu ketidaksesuaian kriteria penerima bantuan iuran menyebabkan masyarakat yang tergolong mampu, masuk dalam daftar penerima bantuan iuran BPJS Kesehatan tersebut. Berdasarkan pengamatan dilapangan terdapat 3 (tiga) faktor utama yang dianggap sebagai penghambat pendataan penerima bantuan iuran BPJS kesehatan di Kelurahan Heledulaa Utara Kecamatan Kota Timur Kota 
Gorontalo yaitu, Pertama kurangnya pengetahuan petugas pendata mengenai panduan teknis pendataan.

Petugas pendata tidak semuanya memahami atau menguasai panduan tehnik pendataan sehingga petugas pendata masih kebingungan dalam menentukan kategori penerima bantuan iuran (PBI) BPJS.Padahal panduan tehnik pendataan dapat menjadi alat bantu bagi petugas pendata sehingga keseragaman persepsi dari petugas pendata dalam menentukan masyarakat yang layak atau tidak masuk dalam kategori PBI BPJS pada saat pendataan akan terlaksana.

Selain itu pendataan yang dilakukan masih belum optimal karena masih manual dengan hanya menggunakan album tanpa dinput ke komputer sehingga data yang ada dapat tercecer atau bahkan hilang. Padahal data mungkin saja diperlukan kembali terutama dalam proses validasi dan verifikasi untuk memperbaharui data tersebut. Yang ketiga adalah proses verifikasi dan validasi yang dilakukan belum berkala sehingga kadang data yang ada terkesan lama padahal seharusnya validasi dan verfikasi data oleh petugas pendata dilakukan minimal 6 bulan sekali agar data yang diperoleh diperbaharui sehingga masyarakat penerima bantuan iuran yang telah meninggal misalnya dapat digantikan dengan masyarakat yang lain.

\section{PERMASALAHAN}

Berdasarkan yang diuraikan di atas, maka rumusan masalah dalam penelitian ini adalah faktor-faktor apa yang menghambat pendataan penerima bantuan iuran BPJS Kesehatan di
Kelurahan Heledulaa Utara kecamatan Kota Timur Kota Gorontalo?

\section{TUJUAN Dan MANFAAT PENELITIAN}

\section{Tujuan Penelitian}

Penelitian ini bertujuan untuk memperoleh gambaran tentang Faktorfaktor Penghambat Pendataan Penerima Bantuan Iuran BPJS Kesehatan di Kelurahan Heledulaa Selatan Kecamatan Kota Timur Kota Gorontalo.

\section{Manfaat Penelitian}

Manfaat yang dapat diambil dari penelitian ini adalah sebagai berikut; Secara Teoritis, penelitian ini diharapkan kiranya dapat dijadikan sebagai bahan informasi yang berharga dalam mengembangkan ilmu pengetahuan, khususnya dalam bidang ilmu administrasi dan menjadi bahan bacaan serta bahan pertimbangan untuk mengkaji masalah yang sama bagi peneliti berikutnya dimasa yang akan datang.

Manfaat Praktis Penelitian ini diharapkan dapat menjadi bahan informasi serta bahan masukan bagi Kelurahan Heledulaa Utara Kecamatan Kota Timur Kota Gorontalo.

\section{METODE PENELITIAN}

Jenis penelitian yang digunakan adalah penelitian deskriptif kualitatif yakni penelitian yang bertujuan untuk mendeskripsikan atau menggambarkan fakta-fakta di lapangan yang berkaitan dengan objek penelitian. Menurut Sugiyono (2009:15) Penelitian kualitatif adalah suatu metode 
penelitian yang berlandaskan pada filsafat postpositivisme, digunakan untuk meneliti pada kondisi objek yang alamiah dimana peneliti adalah sebagai instrumen kunci atau pengambilan, sampel sumber data dilakukan secara purposive, tehnik pengumpulan triangulasi, analisis data bersifat induktif/kualitatif dan hasil penelitian kualitatif lebih menekankan makna daripada generalisasi.

\section{Fokus Penelitian}

Fokus penelitian ini adalah Faktor-faktor Penghambat Pendataan Penerima Bantuan Iuran (PBI) BPJS Kesehatan Kelurahan Heledulaa Utara Kecamatan Kota Timur Kota Gorontalo dengan indikator pengetahuan, sistem pendataan dan verifikasi dan validasi.

Teknik Pengumpulan data dalam penelitian ini dimaksudkan untuk memperoleh data yang relevan dan akurat dengan masalah penelitian. Teknik pengumpulan data tersebut adalah teknik observasi, teknik wawancara dan teknik dokumentasi.

Analisis data ialah langkah selanjutnya untuk mengelola data dimana data yang diperoleh, dikerjakan dan dimanfaatkan sedemikian rupa untuk menyimpulkan persoalan yang diajukan dalam menyusun hasil penelitian. Dalam model ini terdapat 3 (tiga) komponen pokok. Seperti yang dikemukan oleh Miles dan Huberman (Dalam Sugiyono, 2012 : 92-99). (1) Reduksi Data (Data Reduction); (2) Penyajian Data (Data Display) (3) Verifikasi Data (Verification Data).

\section{HASIL PENELITIAN DAN PEMBAHASAN}

Berdasarkan

beberapa pernyataan atau hasil wawancara dengan informan dapat disimpulkan bahwa proses verifikasi dan validasi yang dilakukan belum berjalan efektif, hal ini terlihat dari masih ada sebagian masyarakat yang tidak hadir dalam rapat atau pertemuan yang dilaksanakan guna membahas verifikasi dan validasi data penerima bantuan iuran (PBI). Hal tersebut dikarenakan kurangnya informasi kepada masyarakat mengenai pelaksanaan rapat atau pertemuan yang membahas tentang verifikasi dan validasi penerima bantuan iuran (PBI) tersebut.

\section{Pembahasan}

Berdasarkan hasil penelitian
yang dilakukan berdasarkan indikator fokus yang diukur maka dapat diketahui bahwa pendataan penerima bantuan iuran (PBI) BPJS Kesehatan di kelurahan Heledulaa Utara Kecamatan Kota Timur yaneg diukur melalui fokus yang digunakan seperti pengetahuan petugas, sistem pendataan dan proses verifikasi dan validasi dinilai belum efektif.

Pengetahuan adalah informasi atau maklumat yang diketahui atau disadari oleh seseorang. Pengetahuan termasuk, tetapi tidak dibatasi pada deskripsi, hipotesis, konsep, teori, prinsip dan prosedur yang secara Probabilitas Bayesian adalah benar atau berguna. Sedangkan yang dimaksudkan pengetahuan dalam penelitian ini adalah pengetahuan yang dimiliki oleh petugas pendata dalam melaksanakan pendataan penerima bantuan iuran (PBI) BPJS kesehatan di Kelurahan Heledulaa Utara 
Kecamatan Kota Timur Kota Gorontalo.

Berdasarkan hasil penelitian menunjukan bahwa pengetahuan dan pemahaman petugas pendata mengenai tehnik dan mekanisme pendataan masih rendah. Hal ini terlihat dari masih adanya petugas pendata yang mengalami kesulitan ataupun kebingungan dalam melakukan pendataan sehingga data yang ada tidak sesuai, dan menyebabkan kendala pada saat pengimputan. . Selain itu tingkat pendidikan para petugas pendata yang juga masih rendah dan kurangnya pelatihan dan bimbingan teknis mengenai panduan teknis pendataan juga menjadi penyebabnya.

Pendataan adalah kenyatan mengambarkan suatu kejadiankejadian nyata. yaitu mengumpulkan semua data yang diperlukan, mengolah dan menyajikan data sesuai yang diharapkan. Sedangkan hasil dari pendataan adalah data, yaitu catatan atas kumpulan fakta. Data yang baik harus obyektif dan dapat dipertanggungjawabkan. Data dipergunakan dalam pengambilan keputusan sehingga kevalidan data akan meningkatkan ketepatan sasaran dalam mengambil keputusan. Adapun sistem pendataan yang dimaksudkan dalam penelitian ini adalah sistem pendataan yang digunakan oleh petugas pendata Penerima Bantuan Iuran (PBI) BPJS. Di kelurahan Heledulaa Utara Kecamatan Kota Timur Kota Gorontalo.

Berdasarkan hasil penelitian menunjukan bahwa sistem pendataan yang dilakukan oleh para petugas pendata masih sangat sederhana. Hal ini terlihat dari fasilitas atau alat yang digunakan oleh petugas pendata berupa alat tulis, seperti buku album, spidol/pulpen buku panduan teknis. Selain itu kurangnya fasilitas seperti komputer untuk pengimputan data juga menjadi salah satu alasannya.

Verifikasi adalah pernyataan logis tentang suatu hal yang telah dipecahkan dengan menggunakan metode verifikasi empirik. Pengertian verifikasi data adalah pembentukan kebenaran teori, fakta, dan sebagainya atas data yang dikumpulkan untuk diolah dan dianalisis agar dapat diuji secara hipotesis. Adapun Validasi adalah suatu tindakan yang membuktikan bahwa suatu proses/metode dapat memberikan hasil yang konsisten sesuai dengan spesifikasi yang telah ditetapkan dan terdokumentasi dengan baik. Sedangkan Verifikasi dan Validasi yang dimaksud dalam penelitian ini adalah verifikasi dan validasi data penerima bantuan iuran (PBI) BPJS kesehatan di Kelurahan Heledulaa Utara Kecamata Kota Timur.

Berdasarkan hasil penelitian menunjukan bahwa proses verifikasi dan validasi yang dilakukan belum berjalan efektif, hal ini terlihat dari masih ada sebagian masyarakat yang tidak hadir dalam rapat atau pertemuan yang dilaksanakan guna membahas verifikasi dan validasi data penerima bantuan iuran (PBI). Hal tersebut dikarenakan kurangnya informasi kepada masyarakat mengenai pelaksanaan rapat atau pertemuan yang membahas tentang verifikasi dan validasi penerima bantuan iuran (PBI) tersebut. Secara keseluruhan berdasarkan hasil penelitian yang dilakukan oleh penulis berdasarkan fokus yang diukur maka dapat diketahui bahwa pendataan Penerima Bantuan Iuran (PBI) BPJS kesehatan 
di Kelurahan Heledulaa Utara Kecamatan Kota Timur Kota Gorontalo yang diukur melalui fokus yang digunakan seperti pengetahuan petugas, sistem pendataan dan verifikasi dan validasi. $\quad \mathrm{Hal}$ ini dikarenakan, kurangnya pelatihan dan bimbingan teknis mengenai panduan teknis pendataan bagi para petugas pendata, sistem pendataan yang masih sangat sederhana dan data yang tidak langsung diimput ke komputer serta proses verifikasi dan validasi data yang terhambat oleh ketidakhadiran masyarakat dalam rapat dan pertemuan penerima bantuan iuran (PBI) BPJS Kesehatan.

\section{KESIMPULAN}

Dari hasil penelitian dan pembahasan seperti yang telah diuraikan sebelumnya, maka dapat disimpulkan sebagai berikut:

1. Dilihat dari aspek pengetahuan petugas pendata masih cukup rendah. Hal ini terlihat dari masih adanya pendata yang kebingungan dalam melakukan pendataan penerima bantuan iuran (PBI) BPJS dikarenakan kurangnya pelatihan ataupun bimbingan teknis mengenai panduan teknis pendataan tersebut. Selain itu tingkat pendidikan para petugas juga masih rendah sehingga tidak memiliki kemampuan untuk mengoperasikan komputer.

2. Dilihat dari aspek sistem pendataan yang dilakukan oleh para petugas pendata masih sangat sederhana. Hal ini terlihat dari fasilitas atau alat yang digunakan oleh para petugas berupa buku album, dan pulpen atau spidol dan panduan teknis pendataan.
3. Dilihat dari aspek verifikasi dan validasi yang dilakukan masih belum maksimal. Hal ini terlihat dari ketidakhadiran sebagian masyarakat pada saat pelaksanaan rapat atau pertemuan yang membahas verifikasi dan validasi data sehingga data yang ada tidak dapat diperbaharui dan terkesan lama.

4. Secara keseluruhan berdasarkan hasil penelitian yang dilakukan oleh penulis berdasarkan fokus yang diteliti maka dapat diketahui bahwa pendataan penerima bantuan iuran (PBI) BPJS Kesehatan Kelurahan Heledulaa Utara Kecamatan Kota Timur yang diukur melalui fokus yang digunakan seperti pengetahuan petugas, sistem pendataan, dan verifikasi dan validasi dinilai belum efektif. Hal ini dikarenakan, masih rendahnya pengetahuan yang dimilki petugas pendata mengenai tehnik pendataan penerima bantuan iuran (PBI) BPJS Kesehatan, sistem pendataan yang dilakukan masih sangat sederhana serta ketidakhadiran masyarakat dalam rapat dan pertemuan sehingga proses verifikasi dan validasi kembali menjadi terhambat.

\section{SARAN}

Sehubungan dengan kesimpulan hasil penelitian yang diuraikan tersebut diatas, perlu disarankan sebagai berikut:

1. Perlunya meningkatkan pengetahuan dan wawasan petugas pendata dengan memberikan bimbingan teknis atau mengikutsertakan petugas pendata dalam pelatihan-pelatihan tentang panduan tehnik pendataan 
Penerima Bantuan Iuran (PBI) BPJS Kesehatan.

2. Perlunya mengubah sistem pendataan atau yang digunakanoleh petugas pendata dengan memfasilitasi petugas pendata dengan fasilitas atau alat yang lebih canggih seperti komputer ataupun smartphone.

3. Perlunya menyadarkan masyarakat akan pentingnya rapat pertemuan verifikasi dan validasi data penerima bantuan iuran (PBI), serta lebih giat menginformasikan jadwal rapat atau pertemuan kepada masyarakat.

4. Perlunya dilakukan perbaikan secara menyeluruh untuk mendapatkan data penerima bantuan iuran (PBI) BPJS Kesehatan yang lebih akurat dengan melakukan perbaikanperbaikan khususnya pada pengetahuan petugas pendata, metode penelitian dan proses verfikasi dan validasi.

\section{DAFTAR PUSTAKA}

Abdullah, Ma"eruf. 2014. Manajemen dan Evaluasi Kinerja Karyawan. Aswaja. Yogyakarta: Pressindo.

Agustino, Leo. 2008. Dasar-dasar Kebijakan Publik Bandung: Alfabeta

Ali, Faried. 2011 Teori dan Konsep Administrasi: dari Pemikiran Paradigmatik menuju Redefinisi. Jakarta: PT. Raja Grafindo Persada.

Alimul, Hidayat A.A. 2010. Metode Penelitian Kesehatan Paradigma Kuantitatif. Jakarta: Heath Books
Amirullah. 2015.

Pengantar Manajemen. Jakarta: Mitra Wacana Media.

Arikunto, S. 2010. Prosedur Penelitian: Suatu Pendekatan Praktik. (Edisi Revisi). Jakarta: Rineka Cipta

Athoillah, Anton. 2010. Dasar-Dasar Manajemen. Bandung: CV Pustaka

Bangun, Wilson. 2008. Intisari Manajemen. Bandung: PT. Refika Aditama.

Daryanto H.M. 2011, Sari Kuliah Manajemen Pemasaran, Bandung: PT Sarana Tutorial Nurani Sejahtera Durianto,

Dewi, Irra Chrisyanti, 2011. Pengantar Ilmu Administrasi, Jakarta: PT Prestasi Pustakaraya.

Hamid, Abdul., 2007. Teori Belajar Dana Pembelajaran. Jakarta: Rineka Cipta.

Handoko, T. Hani. 2009, Manajemen, Cetakan Duapuluh. Yogyakarta: BPEE.

Hasibuan, Malayu. 2010. Manajemen Sumber Daya Manusia. Jakarta: Bumi Aksara.

Islamy, Irfan. 2009. Prinsip- prinsip Perumusan Kebijaksanaan Negara. Jakarta: Bumi Aksara.

Kumorotomo,Wahyudi. dan Agus, Subando Margono. 2011. Sistem Informasi Manajemen Dalam Organisasi-Organisasi Publik. Yogyakarta: Gadjah Mada University Press

Manullang, 2008. DasarDasar Manajemen. Yogyakarta: Ghalia Indonesia. 2012. Dasar-Dasar Manajemen. Jakarta: Ghalia Indonesia.

Miles, Mattew B. A, Michael Huberman. 2007. Analisis Data 
Kualitatif, Buku Sumber Tentang Metode-Metode Baru. Jakarta: Universitas Indonesia Press

Nawawi, Ismail. 2009. Public Policy, Analisis,Strategi Advokasi Teori dan Praktek. Surabaya: PMN.

Purwanto, Ngalim. 2010. PrinsipPrinsip dan Teknik Evaluasi Pengajaran. Bandung: PT. Remaja Rosdakarya

Ratminto dan Atik Septi Winarsih. 2010. Manajemen pelayanan. Yogyakarta: Pustaka Pelajar

Sagala, Syaiful 2009. Konsep dan Makna Pembelajaran. Bandung: Alfabeta

Siagian, Sondang P. 2008. Manajemen Sumber Daya Manusia. Jakarta: PT Bumi Aksara.

Simamora Henry. 2006. Manajemen Sumber Daya Manusia. Cetakan kedua. Yogyakarta: STIE TKPN.

Suandi, I Wayan. 2010. Eksistensi Kebijakan Publik dan Hukum dalam Penyelenggaraan Pemerintah Daerah. Jurnal Ilmiah Fakultas Ilmu Sosial dan Ilmu Politik Vol. I (1), 13

Sudjana, Nana. 2010. Penilain Hasil Proses Belajar Mengajar, Bandung: Remaja Rosdakarya.

Sugiyono. 2009 Metode Penelitian Kuantitatif dan Kualitatif Bandung: CV. Alfabeta. 2012. Metode Penelitian Administrasi. Bandung: Alfabeta. 2013. Metode Penelitian Kuantitatif Kualitatif dan $R \& D$. Bandung: Alfabeta.

Suprayogi. 2011. Konsep Dan Perkembangan Ilmu Di Indonesia Administrasi Publik. Yogyakarta: Graha Ilmu
Sutabri, Tata. 2012. Analisis Sistem Informasi. Yogyakarta: Andi.

Usman, Husaini. 2013. Manajemen. Teori, Praktik, dan Riset Pendidikan. Edisi keempat. Jakarta: Bumi. Aksara

Ulber, Silalahi. 2009. Metode Penelitian sosial Bandung: PT. Refika Aditama

Tachjan. 2008. Implementasi Budaya Unggulan di Industri Menuju World Class. Jakarta: Menara Tunggal.

Terry, George R. Dan Rue, Leslie W. 2010. Dasar-dasar Manajemen. Jakarta: Bumi Aksara.

Veitzal, Rivai. 2010. Manajemen Sumber Daya Manusia Untuk Perusahaan. Jakarta: PT. Raja Grafindo Persada

Wahab Abdul, Solichin. 2008. Analisis Kebijakan: Dari Formulasi ke Implementasi Kebijakan Negara. Edisi Kedua. Jakarta: Bumi Aksara.

Wibowo. 2011. Manajemen Kinerja. Jakarta: Raja Grafindo Persada.

Wijayanti, Irine Diana Sari, 2008. Manajemen.Yogyakarta: Mitra Cendikia Press.

Winarno, Budi. 2007. Kebijakan Publik:Teori dan Proses. Yogyakarta: Med Press. . 2012. Kebijakan Publik Teori, Proses, dan Studi Kasus. Yogyakarta: CAPS.

\section{Sumber Lain}

UU Nomor 23 tahun 1992

UU Nomor 40 tahun 2004

UU 24 Tahun 2011 tentang Badan Penyelenggara Jaminian Sosial.

PP Nomor 101 tahun 2012 tentang Bantuan Iuran Jaminan Kesehatan dan pendataan Fakir miskin dan Orang tidak mampu 
Keputusan Menteri Sosial No.

146/Huk/2013 tentang penetapan

Kriteria. 